\title{
Stress distribution of molars restored with minimal invasive and conventional technique: a 3-D finite element analysis
}

\author{
Sunmi Yang', Seon-mi Kim¹, Namki Choi', Jae-hwan Kim¹, Sung-Pyo Yang², Hongso Yang $3 *$ \\ 'Department of Pedodontics, School of Dentistry, Chonnam National University, Gwangju, Republic of Korea \\ 2Department of Bio and Brain Engineering, KAIST, Daejon, Republic of Korea \\ ${ }^{3}$ Department of Prosthodontics, School of Dentistry, Chonnam National University, Gwangju, Republic of Korea
}

Purpose: This study aimed to analyze stress distribution and maximum von Mises stress generated in intracoronal restorations and in tooth structures of mandibular molars with various types of cavity designs and materials. Materials and Methods: Threedimensional solid models of mandible molar such as $\mathrm{O}$ inlay cavity with composite and gold (OR-C, OG-C), MO inlay cavity with composite and gold (MR-C, MG-C), and minimal invasive cavity on occlusal and proximal surfaces (OR-M, MR-M) were designed. To simulate masticatory force, static axial load with total force of $200 \mathrm{~N}$ was applied on the tooth at 10 occlusal contact points. A finite element analysis was performed to predict stress distribution generated by occlusal loading. Results: Restorations with minimal cavity design generated significantly lower values of von Mises stress (OR-M model: 26.8 MPa; MR-M model: $72.7 \mathrm{MPa}$ ) compared to those with conventional cavity design (341.9 MPa to $397.2 \mathrm{MPa}$ ). In tooth structure, magnitudes of maximum von Mises stresses were similar among models with conventional design (372.8 - 412.9 MPa) and models with minimal cavity design (361.1 - 384.4 $\mathrm{MPa}$ ). Conclusion: Minimal invasive models generated smaller maximum von Mises stresses within restorations. Within the enamel, similar maximum von Mises stresses were observed for models with minimal cavity design and those with conventional design. (J

Dent Rehabil Appl Sci 2018;34(4):297-305)

Key words: finite element analysis; inlay; minimal cavity design; stress; composite

\section{Introduction}

To manage decayed lesions, conventional concept of cavity design for restoration not only focuses on dental caries prevention, but also focuses on retention and resistance of the restoration. This means that the cavity must be deep enough with design features of parallel walls and flat floors. In addition, all unsupported enamel structure should be removed. A traditional approach to control caries inevitably leads to an excessive tooth reduction. ${ }^{1}$

*Correspondence to: Hongso Yang

Professor, Department of Prosthodontics, School of Dentistry, Chonnam National University, 33 Youngbong-ro, Buk-gu, Gwangju, 520757, Republic of Korea Tel: +82-62-530-5823, Fax: +82-62-530-0130, E-mail: yhsdent@jnu.ac.kr Received: October 22, 2018/Last Revision: December 2, 2018/Accepted: December 6, 2018
The concept of minimal interventional dentistry has evolved due to improved understanding of caries processes and the development of adhesion restorative materials. ${ }^{2}$ With the paradigm shift from retentive restorations to conservative restorations, less invasive cavity preparation is increasingly emphasized. ${ }^{3-6}$ From a clinical point of view, it is questionable whether fragile enamel walls without supporting dentin should be removed or preserved. It has been assumed that bonded composite will strengthen the tooth when the enamel has lost its dentin support.

CopyrightC 2018 The Korean Academy of Stomatognathic Function and Occlusion. (c) It is identical to Creative Commons Non-Commercial License. 
However, such assumption is based on clinical evaluations or clinical cases reports. ${ }^{7-11}$ Such biomechanical assumption that the composite can strengthen the teeth has not been fully verified.

Several studies have reported the effect of cavity design on fracture resistance of teeth and restoration by occlusal loading. ${ }^{12-14}$ Most works on fracture mechanism in restored teeth are related to in vivo or in vitro experimental analyses. ${ }^{15-18}$ Modern computer aided design and finite element analysis (CAD-FEA) methodologies play an essential role in biomedical investigations of clinical situations in various dental fields. ${ }^{19-26}$

When practiced in living subjects, some dental research studies are expensive and ethically doubtful. Conversely, using virtual models and simulations can improve investigation performance, reduce the cost of in vitro and in vivo experiments, and improve profitability. $^{27}$

The aim of this study was to compare stress distribution and maximum von Mises stress generated in intracoronal restorations and tooth structures of mandibular molars using three-dimensional FEA method. The following independent variables were investigated: (1) type of cavity design (conventional versus minimal); and (2) type of restorative materials (composite resin versus gold alloy).

\section{Materials and Methods}

\section{Three-dimensional solid model generation}

Mandibular molar tooth was scanned using a 3-D scanner (Freedom HD, DOF Inc, Seoul, Korea). Obtained surface contours and meshes were then imported into SolidWorks 2015 software (Dassault Systems Solid-Works Corp, Waltham, USA). Threedimensional solid model of intact mandibular molar was generated using a "SCANto3D" add-in module (Fig. 1A).

Interfacial surface between pulp chamber and dentin and interfacial surface between dentin and enamel were made by lofting technique of the CAD program according to the anatomy of natural tooth (eHuman 3-D Tooth Atlas 7.6, eHuman Inc, Fremont, USA).

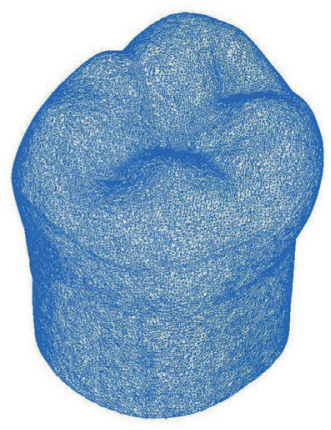

A

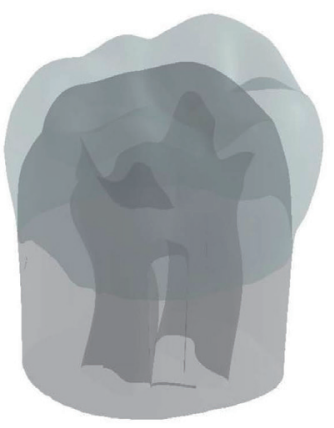

B
Fig. 1. (A) Stereolithography (STL) scan image of mandibular first molar. (B) 3D CAD model of pulp, dentin, and enamel were generated and assembled.

Once enamel, dentin, and pulp 3-D volumes were generated, Boolean operations were used to ensure congruence between related interfacial surfaces. For instance, dentin volume was created by subtracting pulp cavity volume. Enamel 3-D volume was then obtained by subtracting dentin volume (Fig. 1B). All solid models were derived from the three-dimensional solid model of the intact mandibular molar. ${ }^{27}$

\section{Cavity preparation design}

Based on the three-dimensional CAD model of un-restored mandibular molar tooth, inlays with conventional cavity model and composite filling with minimal invasive preparation model were made. Four 3-D experimental models were designed and created: (1) O cavity with conventional design (OR-C, OG-C models); (2) MO cavity with conventional design (MR-C, MG-C models); (3) O cavity with minimal design (OR-M model); and (4) D cavity with minimal design (MR-M model). Shape and dimensions of intracoronal restorations were taken from the literature. $^{28}$

All inlays with conventional design cavities had pulpal and axial walls with at least $0.6 \mathrm{~mm}$ dentin thickness over the pulp while gingival walls of proximal boxes were located $0.4 \mathrm{~mm}$ above cementoenamel junction. The narrowest portion of the preparation was $1.0 \mathrm{~mm}$ faciolingually, which was located between buccal and lingual cusp tips. The cavity ex- 
tended the full length of the occlusal groove, including mesial and distal pits with their radiating grooves. The pulpal wall was flat horizontally. The occlusocervical thickness of inlay was between $0.7 \mathrm{~mm}$ and 2.6 $\mathrm{mm}$ in $\mathrm{O}$ cavity. In $\mathrm{MO}$ inlay cavity, proximal boxes were extended proximally from the occlusal cavity. The shape of the proximal box was on straight lines or planes with thickness of at least $0.8 \mathrm{~mm}$. Minimally invasive models (OR-M, DR-M) preserved the unsupported enamel and removed the minimum tooth structure in spherical form, which was limited to the area of dental caries lesion (Fig. 2). Volumes of restorations were $24.92 \mathrm{~mm}^{3}$ in conventional $\mathrm{O}$ cavity and $46.35 \mathrm{~mm}^{3}$ in conventional MO cavity. Those of OR-M model and MR-M model were $4.13 \mathrm{~mm}^{3}$ and $9.73 \mathrm{~mm}^{3}$, respectively, in minimally invasive cavity (Table 1).

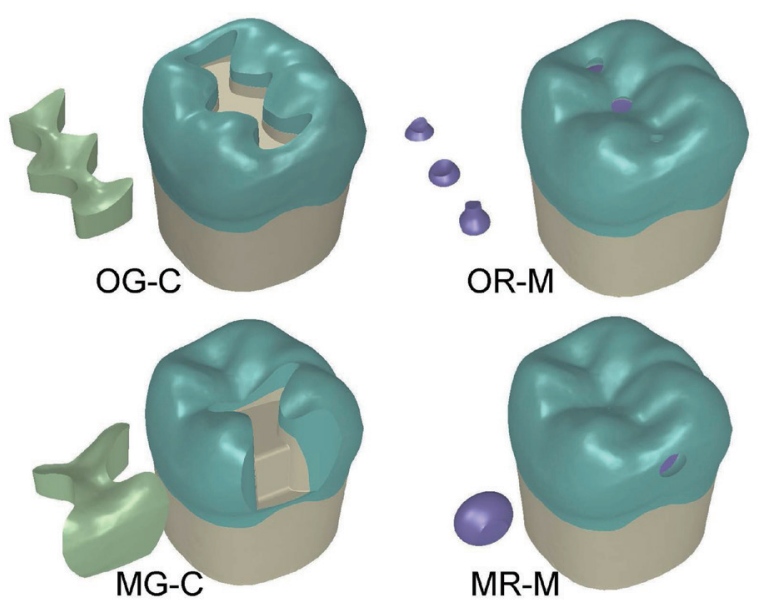

Fig. 2. Two conventional inlay models of O cavity (CG$\mathrm{C}), \mathrm{MO}$ cavity (MG-C), and two minimal invasive designs for occlusal caries (OR-M) and proximal caries (MR-M) models were made.

\section{Finite element analysis}

In minimal cavity design groups, restorative material was composite resin. In conventional cavity design groups, two types of restorative materials were tested: (1) gold alloy $(\mathrm{E}=95.6 \mathrm{GPa}, \mathrm{v}=0.35),{ }^{20}$ and (2) composite resin $(\mathrm{E}=9.5 \mathrm{GPa}, v=0.24) .{ }^{16}$ Material properties of dentin $(\mathrm{E}=18.6 \mathrm{GPa}, v=0.32)^{21}$ and enamel $(\mathrm{E}=84.1 \mathrm{GPa}, \mathrm{v}=0.3)^{20}$ were assigned. All materials were assumed to have linear, elastic, and isotropic properties. The bonding interface between dentin and composite or enamel was considered to be perfect in this experiment. Three-dimensional solid models were meshed with tetrahedral elements. The number of elements and nodes varied according to models (59,009 - 73,064 elements and 89,352 - 108,739 nodes). Fixed zero-displacement in three spatial dimensions ( $\mathrm{X}, \mathrm{Y}$, and $\mathrm{Z}$ ) was assigned to nodes at the bottom surface of the tooth, preventing rigid body displacement for all models. To simulate biting force, a total amount of $200 \mathrm{~N}$ load was applied vertically on the tooth at 10 occlusal contact points (5 buccal cusp points, 3 central fossa points, and each point on both marginal ridges) (Fig. 3). A static finite element analysis (FEA) was performed to predict the stress distribution generated by occlusal loading.

\section{Results}

In order to analyze stress distribution and location, all structures created were isolated from the rest of the model. For each group, peak stresses on restorative materials and abutment teeth were evaluated separately.

Table 1. Experimental models and cavity volume for each restoration

\begin{tabular}{lllr}
\hline Model & Cavity design & Restorative material & Volume of cavity \\
\hline OR-C & O cavity & composite resin & 24.92 \\
OG-C & O cavity & gold alloy & 24.92 \\
OR-M & MCD & composite resin & 4.13 \\
MR-C & MO cavity & composite resin & 46.35 \\
MG-C & MO cavity & gold alloy & 46.35 \\
MR-M & MCD & composite resin & 9.73 \\
\hline
\end{tabular}

MCD: minimal cavity design; Unit: $\mathrm{mm}^{3}$. 


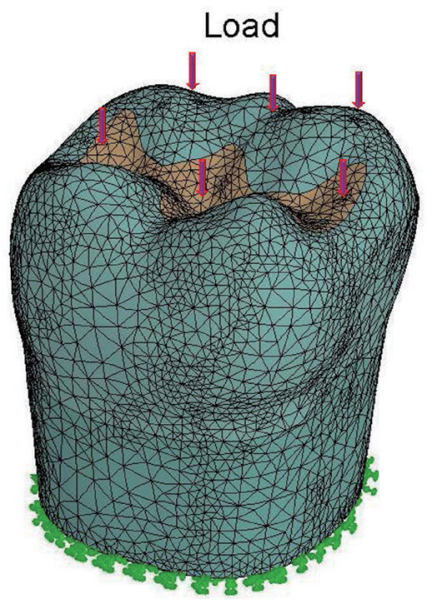

Fig. 3. A total amount of $200 \mathrm{~N}$ axial load was applied at 10 occlusal points: 5 points in buccal cusp area and 5 points in marginal ridges and central fossa area (model OG-C). Solid model with restoration, enamel, dentin, and pulp chamber of the mandibular molar was meshed with tetrahedral elements. Bottom of the model was fixed in all directions as a boundary condition.

\section{Stress distribution in restorations}

Maximum values of von Mises stress within restorations with minimal cavity design generated were significantly lower (OR-M model: 26.8 MPa; MR-M model: $72.7 \mathrm{MPa}$ ) compared to those with conventional cavity design (OR-C model: 397.2 MPa; OG-C model: $341.9 \mathrm{MPa}$; MR-C model: $362.5 \mathrm{MPa}$; MG-C model: $352.6 \mathrm{MPa}$ ).
Regarding the effect of cavity design, minimal invasive designs (OR-M, MR-M) generated 5 to 10 times smaller maximum von Mises stresses than those with conventional inlay designs (Fig. 4). Regarding the effect of dental material, composite resin (OR-C, MR-C) exhibited slightly higher maximum von Mises stresses than gold alloy (OG-C, MG-C) in restorations. Gold inlay (OG-C) showed more favorable and well distributed stresses in the restoration than composite resin inlay (OR-C) (Fig. 5, Fig. 6). Overall, the order of stress intensity in restorations with conventional inlay/minimal cavity filling designs was as follows: OR-C $>$ MR-C $>$ MG-C $>$ OG-C > MR-M > OR-M.

The differences in stress magnitudes over the adjacent enamel along cavosurface margins of composite restorations (OR-C, OR-M, MR-M) were distinguished. In terms of stress location, high concentrations of von Mises stress on surfaces of restorations were found near the occlusal contact areas where biting forces were applied (Fig. 7).

\section{Stress distribution in abutment teeth}

In tooth structure, magnitudes of maximum von Mises stresses in models with conventional design were between $372.8 \mathrm{MPa}$ and $412.9 \mathrm{MPa}$, while those in models with minimal cavity designs were between 361.1 $\mathrm{MPa}$ and 384.4 MPa. The gold O cavity inlay (OG-C) produced the highest von Mises stress (412.0

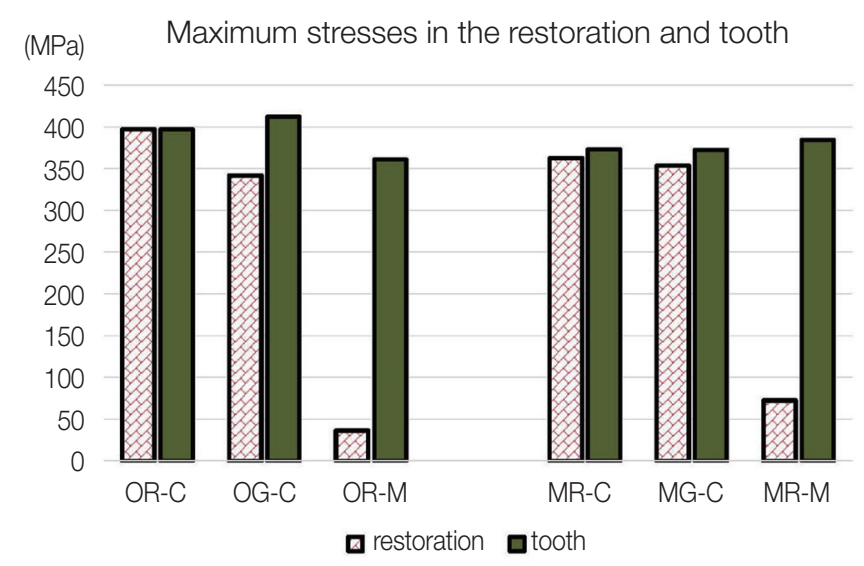

Fig. 4. Minimal invasive cavity designs (OR-M, MR-M) produced very small maximum von Mises stress magnitude compared to conventional inlay designs in the restoration. There were no significant differences in maximum stress magnitudes within the abutment tooth among models. 


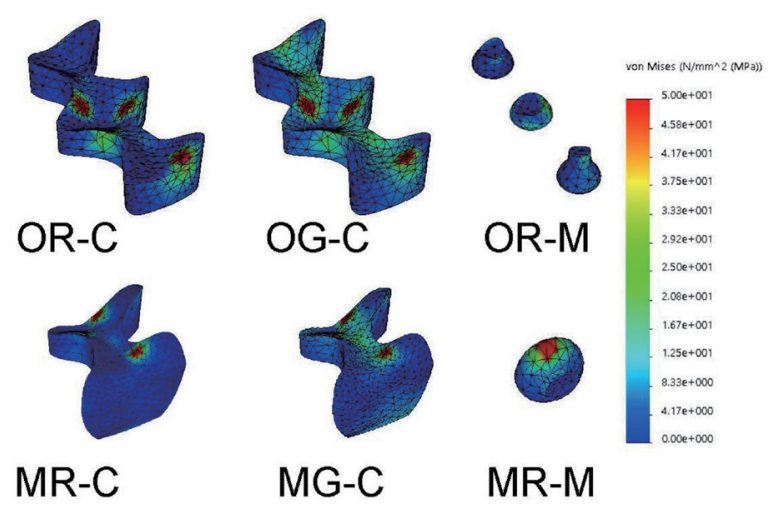

Fig. 5. Von Mises stress distribution generated by occlusal loading in the restoration of each experimental model. Models with composite (OR-C, MR-C) showed stress concentration at the loading area. Models with gold alloy (OG-C, MG-C) showed widely distributed stresses within the restorations.

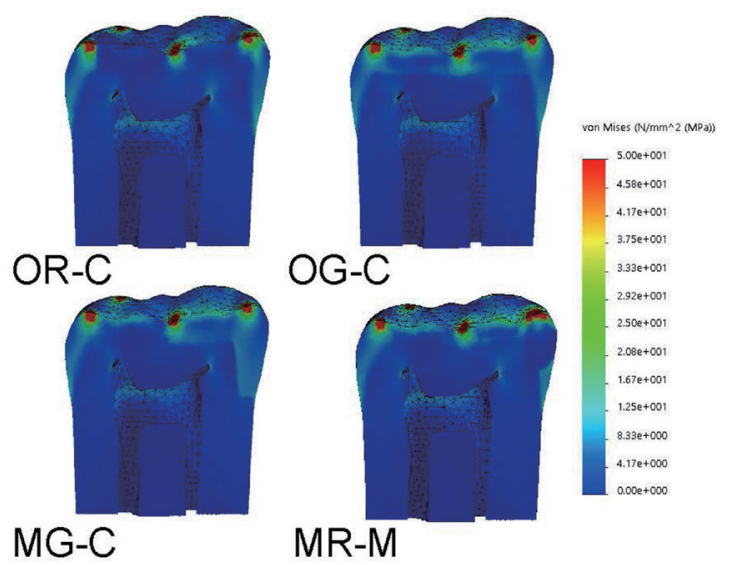

Fig. 6. Von Mises stress distribution by occlusal loading in the restoration and the abutment tooth with M-D cross-sectional view. Models of OG-C and MG-M produced well distributed stress inside the gold restoration.

$\mathrm{MPa}$ ) while the composite minimal $\mathrm{O}$ cavity design (OR-M) generated the lowest von Mises stress (361.1 $\mathrm{MPa}$ ) (Fig. 4). When comparing all experimental models, maximum stress values generated in the abutment teeth were close to one another (i.e., between conventional/minimal invasive cavity designs and tested restorative materials).

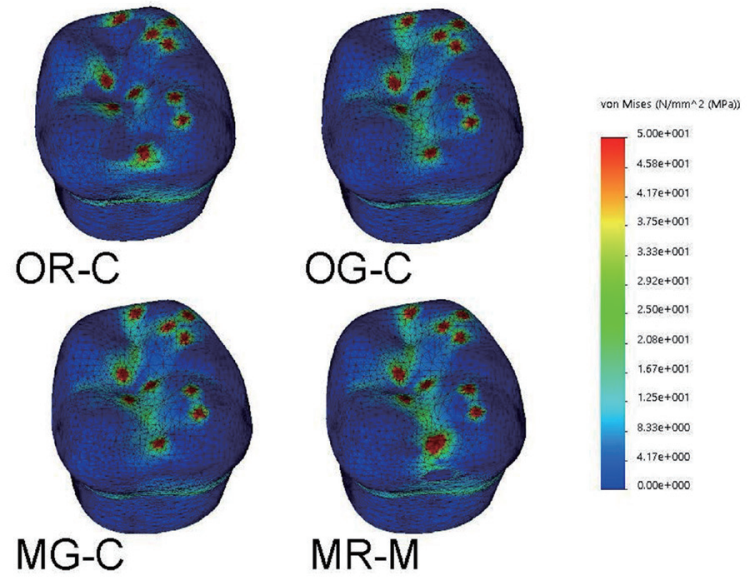

Fig. 7. Cavosurface margin between resin restorations (OR-C, MR-M) and tooth structures showed significant difference in stress gradient and distribution. Peak stress was observed at the occlusal loading area and cemento-enamel junction in all models.
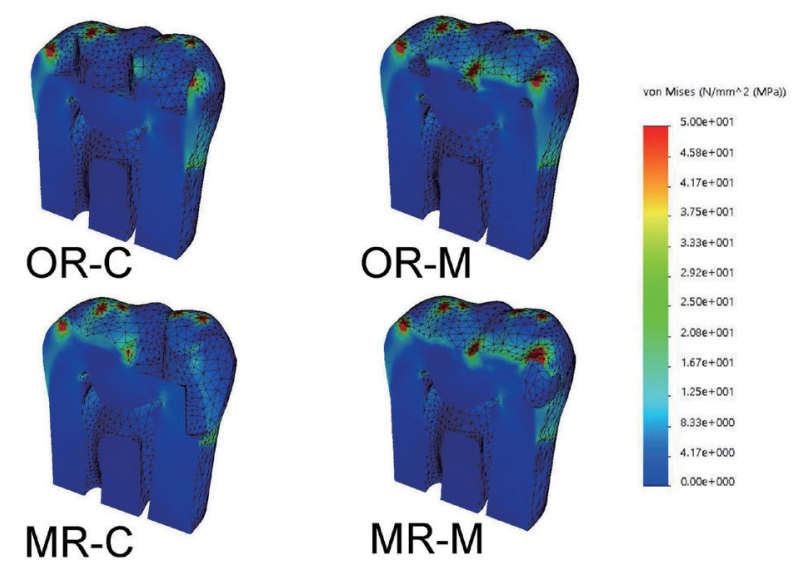

Fig. 8. Von Mises stress distribution by occlusal loading in the abutment tooth with M-D cross-sectional view. Note stress concentration was observed around the occlusal contact area, pulp horns, and cemento-enamel junction.

In terms of stress distribution patterns in enamel and dentin, similar results were observed for all experimental models. High stress concentrations were found at the enamel surface near buccal cusp tips, central fossa, and marginal ridges where axial occlusal forces were applied (Fig. 6, Fig. 7, and Fig. 8). 


\section{Discussion}

Preservation of sound tooth structures is the primary goal of restorative dentistry. Even if removal of additional dental tissue is necessary, protecting the remaining tooth structure from undesirable mechanical responses should be considered. Tooth preparation designs proposed for posterior inlay restorations have been based upon recommendations made by GV Black for cast metal and amalgam, resulting in considerable tooth structure removal with opposing walls that are parallel. ${ }^{28}$ The preparation design for an indirect restoration must satisfy a balance between preserving the tooth structure and maximizing the strength of the restoration. However, there is a problem within the concept of the original GV Black classification since it identifies the position of lesion and prescribes cavity design regardless of the size and extent of carious lesion. Recently, the Academy of Operative Dentistry European Section has considered adhesively bonded resin composites for use in direct minimal intervention approaches to restore posterior teeth, emphasizing the importance of the practice of evidence-based minimal intervention dentistry to extend the longevity of restorations. ${ }^{3}$

Masticatory loads in the posterior region are much higher than those in the anterior region. Stress concentrations can manifest themselves in various forms of clinical failures such as tooth fracture and fracture of restorative body. The main purpose of this research was to evaluate the maximum stress values and stress distribution in intracoronal restorations and the tooth after occlusal loading to identify failure possibility under various types of cavity designs and materials.

St-Georges et al. ${ }^{14}$ have reported fracture resistance of prepared teeth restored with bonded inlay for MOD preparations can weaken the teeth by approximately 59\%. Under compressive load testing, composite and ceramic inlay restorations do not restore the original strength of the teeth. Removal of marginal ridges, increase in the depth and width of inlay cavity, and increased preparation in the proximal box formation are main reasons for the decrease in resistance. The current minimally invasive dentistry advo- cates conservative principles of cavity preparation. Small isolated lesions should be treated individually, not interconnected, as common practice for conventional inlay preparations. Furthermore, the preparation should not be extended beyond dimensions of the caries lesion so that the enamel unsupported by dentin is preserved.

The traditional approach to control caries inevitably leads to an excessive tooth reduction. FEA results from Wayne et al. ${ }^{26}$ have revealed that larger restoration volume proportion will result in higher dentinenamel stresses under static loading. This result suggests that minimal invasive cavity can produce stresses that are more favorable biomechanically. In our study, tooth structure prepared with conventional inlay designs removed five times greater volume than that with minimal invasive cavity designs (Table 1). Within restorations, minimal invasive models generated smaller peak stress while similar magnitudes of stresses were produced within the abutment tooth. Low magnitudes of von Mises stresses observed in our experiment models with minimal invasive cavity contradicted GV Black's classical principles of cavity preparation from the biomechanical point of view. Our findings could serve as a basis for preserving as many intact tooth structures as possible (Fig. 4, Fig. 5, Fig. 6, and Fig. 7). A strengthening effect of the enamel without dentin support in minimally invasive technique could be expected in clinical situation of bonded composite restoration.

Guven et al. ${ }^{22}$ have analyzed the influence of inlay cavity design by FEA and reported that cavities with rounded corners showed less stress than those with rectangular corners due to improved stress distribution capabilities of rounded corners. The model of conventional inlay has a box-shaped cavity with sharp margins. This might have increased the maximum stress of the model in our study.

Currently, composite resin as well as metal alloy and dental ceramic represent logical options for restorations in posterior teeth. The restorative material is a factor that can affect the biomechanics during occlusal loading. Gold restorative material tends to concentrate more stress inside the inlay, resulting in lower cusp deflection than the resin. ${ }^{15}$ In our study, 
gold inlay (OG-C) showed well distributed smaller peak stresses in the restoration than the composite resin inlay (OR-C). Interestingly, in contrast to cavity design of inlays/filling, only a small difference was observed among maximum stresses by different restorative materials in each experimental group (Fig. 4). Thus, using proper cavity design may be more important than using a particular restorative material.

The fracture resistance of teeth restored with inlay/filling is very complex. It is impossible to include all variables encountered in the oral environment in a computer simulation. ${ }^{19}$ Although von Mises stress concentration cannot predict failure patterns in a computer simulation, higher stress concentrations are related to fracture of restorations and failure of teeth restored with inlays or filling. In oral cavity during function, teeth are loaded with complex and variable forces.

Low magnitudes stresses observed in our experiment models of minimal invasive cavity suggest preserving as many intact tooth structures as possible from a mechanical point of view. Several limitations and weaknesses of computer simulation need to be addressed in the future.

\section{Conclusion}

Finite element analysis was performed to investigate the effect of different cavity preparation designs with various restorative materials on mandibular molar after exposure to a masticatory force. Within the limitations of this study, the following conclusions were drawn:

Models with minimal invasive designs (OR-M, MR-M) generated 5 to 10 times smaller maximum von Mises stress within restorations than those with conventional inlay designs when occlusal load was applied.

Peak stress was generated at the occlusal contact area around marginal ridges or central fossa in all models. Gold inlay (OG-C) showed well distributed and smaller stresses in the restoration than composite resin inlay (OR-C).

Lower magnitudes of von Mises stresses observed in models with minimal invasive cavity design sug- gest that bonded composite can strengthen the tooth when enamel has lost its dentin support.

\section{Acknowledgments}

This work was supported by a grant (CRI 18026-1) of the Chonnam National University Hospital Research Institute.

\section{ORCID}

Sunmi Yang https://orcid.org/0000-0002-9802-0282 Seon-mi Kim https://orcid.org/0000-0001-5103-767X Namki Choi https://orcid.org/0000-0003-4830-8568 Jae-hwan Kim https://orcid.org/0000-0001-8088-6216 Sung-Pyo Yang https://orcid.org/0000-0003-4928-1838 Hongso Yang https://orcid.org/0000-0002-9138-4817

\section{References}

1. Sabbagh J, McConnell RJ, McConnell MC. Posterior composites: Update on cavities and filling techniques. J Dent 2017;57:86-90.

2. Tyas MJ, Anusavice KJ, Frencken JE, Mount GJ. Minimal intervention dentistry - a review. FDI Commission Project 1-97. Int Dent J 2000;50:1-12.

3. Lynch CD, Opdam NJ, Hickel R, Brunton PA, Gurgan S, Kakaboura A, Shearer AC, Vanherle G, Wilson NH. Guidance on posterior resin composites: Academy of Operative Dentistry - European Section. J Dent 2014;42:377-83.

4. Banerjee A. Minimal intervention dentistry: part 7. Minimally invasive operative caries management: rationale and techniques. Br Dent J 2013;214:10711.

5. Ericson D, Kidd E, McComb D, Mjör I, Noack MJ. Minimally Invasive Dentistry - concepts and techniques in cariology. Oral Health Prev Dent 2003;1:59-72.

6. Tassery H, Levallois B, Terrer E, Manton DJ, Otsuki M, Koubi S, Gugnani N, Panayotov I, Jacquot B, Cuisinier F, Rechmann P. Use of new minimum intervention dentistry technologies in caries management. Aust Dent J 2013;58 Suppl 1:40-59.

7. Casagrande L, Laske M, Bronkhorst EM, Huys- 
mans MCDNJM, Opdam NJM. Repair may increase survival of direct posterior restorations - A practice based study. J Dent 2017;64:30-6.

8. Staehle HJ, Wohlrab T, Saure D, Wolff D, Frese C. A 6.5-year clinical follow-up of direct resin composite buildups in the posterior dentition: Introduction of a new minimally invasive restorative method. J Dent 2015;43:1211-7.

9. White JM, Eakle WS. Rationale and treatment approach in minimally invasive dentistry. J Am Dent Assoc 2000;131:13S-9S.

10. Abu-Hanna AA, Mjör IA. Resin composite reinforcement of undermined enamel. Oper Dent 2004;29:234-7.

11. Eidelman E. Composite resin support of undermined enamel in amalgam restorations. Pediatr Dent 1999;21:118-20.

12. Fonseca RB, Fernandes-Neto AJ, Correr-Sobrinho L, Soares CJ. The influence of cavity preparation design on fracture strength and mode of fracture of laboratory processed composite resin restorations. J Prosthet Dent 2007;98:277-84.

13. Yang H, Park C, Shin JH, Yun KD, Lim HP, Park SW, Chung H. Stress distribution in premolars restored with inlays or onlays: 3D finite element analysis. J Adv Prosthodont 2018;10:184-90.

14. St-Georges AJ, Sturdevant JR, Swift EJ Jr, Thompson JY. Fracture resistance of prepared teeth restored with bonded inlay restorations. J Prosthet Dent 2003;89:551-7.

15. Costa A, Xavier T, Noritomi P, Saavedra G, Borges A. The influence of elastic modulus of inlay materials on stress distribution and fracture of premolars. Oper Dent 2014;39:E160-70.

16. Yamanel K, Caglar A, Gülsahi K, Ozden UA. Effects of different ceramic and composite materials on stress distribution in inlay and onlay cavities: 3-D finite element analysis. Dent Mater J 2009;28:661-70.

17. Latino C, Troendle K, Summitt JB. Support of undermined occlusal enamel provided by restorative materials. Quintessence Int 2001;32:287-91.

18. Soares CJ, Martins LR, Pfeifer JM, Giannini M. Fracture resistance of teeth restored with indirectcomposite and ceramic inlay systems. Quintessence
Int 2004;35:281-6.

19. Dejak B, Mlotkowski A. Three-dimensional finite element analysis of strength and adhesion of composite resin versus ceramic inlays in molars. J Prosthet Dent 2008;99:131-40.

20. Jiang W, Bo H, Yongchun G, LongXing N. Stress distribution in molars restored with inlays or onlays with or without endodontic treatment: a threedimensional finite element analysis. J Prosthet Dent 2010;103:6-12.

21. Zarone F, Sorrentino R, Apicella D, Valentino B, Ferrari M, Aversa R, Apicella A. Evaluation of the biomechanical behavior of maxillary central incisors restored by means of endocrowns compared to a natural tooth: a 3D static linear finite elements analysis. Dent Mater 2006;22:1035-44.

22. Guven S, Akdogan M, Oz C, Dogan MS, Unal M, Unal S, Sahbaz C. Three-dimensional finite-element analysis of two ceramic inlay restorations with different cavity designs. Biotechnol Biotechnol Equip 2015;29:579-85.

23. Magne P. Efficient 3D finite element analysis of dental restorative procedures using micro-CT data. Dent Mater 2007;23:539-48.

24. Heo KH, Lim YJ, Kim MJ, Kwon HB. Threedimensional finite element analysis of the splinted implant prosthesis in a reconstructed mandible. J Adv Prosthodont 2018;10:138-46.

25. Zelic K, Vukicevic A, Jovicic G, Aleksandrovic S, Filipovic N, Djuric M. Mechanical weakening of devitalized teeth: three-dimensional Finite Element Analysis and prediction of tooth fracture. Int Endod J 2015;48:850-63.

26. Wayne JS, Chande R, Porter HC, Janus C. Effect of restoration volume on stresses in a mandibular molar: a finite element study. J Prosthet Dent 2014;112:925-31.

27. Ausiello P, Franciosa P, Martorelli M, Watts DC. Numerical fatigue 3D-FE modeling of indirect composite-restored posterior teeth. Dent Mater 2011;27:423-30.

28. Thompson MC, Thompson KM, Swain M. The allceramic, inlay supported fixed partial denture. Part 1. Ceramic inlay preparation design: a literature review. Aust Dent J 2010;55:120-7. 


\section{최소 침습적 충진 및 통상적 인레이 법으로 수복한 대구치의 응력 분포: 3-D 유한 요소 해석}

양선미 ${ }^{1}$, 김선미 ${ }^{1}$, 최남기 ${ }^{1}$, 김재환 $^{1}$, 양성표 $^{2}$, 양홍서 ${ }^{3 *}$

${ }^{1}$ 전남대학교 치의학전문대학교 소아치과학교실

${ }^{2} \mathrm{KAIST}$ 뇌공학 및 의공학과

${ }^{3}$ 전남대학교 치의학전문대학교 보철학교실

목적: 다양한 형태의 공동 설계 및 재료를 이용한 하악 대구치의 치아 구조 및 intracoronal 수복물에서 발생하는 응력 분 포 및 최대 von Mises 응력을 분석하고자 하였다.

연구 재료 및 방법: 콤포지트레진 및 금으로 수복한 통상적 교합면 와동과(OR-C, OG-C) 인접면 와동(MR-C, MG-C) 및 콤포지트레진으로 충전한 최소 침습적 와동을 갖는 교합면 와동(OR-M) 및 인접면 와동(MR-M)의 형상을 하악 삼차원 입체 모델로 설계했다. 저작력을 부여하기 위해 총 교합력 $200 \mathrm{~N}$ 의 정적 축 방향 하중을 10 개의 교합 접촉점에서 치아에 적용했다. 유한 요소 해석은 교합 하중에 의해 생성 된 응력 분포를 예측하기 위해 수행되었다.

결과: 최소 침습적 설계를 가진 수복물은 통상적 와동 설계(341.9 MPa - 397.2 MPa)에 비해 von Mises 응력(OR-M 모델: $26.8 \mathrm{MPa}, \mathrm{MR}-\mathrm{M}$ 모델: $72.7 \mathrm{MPa}$ )의 값이 현저하게 낮았다. 치아 내부에서 최대 von Mises 응력의 크기는 통상적 와동 설계(372.8 - 412.9 MPa) 및 최소 와동 설계(361.1 - 384.4 MPa) 모델에서 유사했다.

결론: 최소 침습성 모델은 수복물 중에서 최소의 von Mises 응력이 생성되었다. 법랑질 내에서는 최대 von Mises 응력이 최소 공동 설계와 기존 설계의 모델에서 유사한 크기로 관찰되었다.

(구강회복응용과학지 2018;34(4):297-305)

주요어: 유한 요소 해석; 인레이; 최소 침습적 충진; 응력; 콤포지트레진

*교신저자: 양홍서

(520757) 광주광역시 북구 용봉로 33 전남대학교 치의학전문대학원

Tel: 062-530-5823 | Fax: 062-530-0130 | E-mail: yhsdent@jnu.ac. kr

접수일: 2018년 10월 22일 | 수정일: 2018년 12월 2일 | 채택일: 2018년 12월 6일 